\title{
KAJIAN PERSPEKTIF PENGEMBANGAN WILAYAH KABUPATEN ROTE NDAO SEBAGAI SALAH SATU KAWASAN EKONOMI KHUSUS
}

\author{
Donny Teguh Santoso Junias ${ }^{1 *}$, Meyulinda Aviana Elim ${ }^{2}$, Raden Setyo Budi Suharto ${ }^{3}$ \\ ${ }_{1,2,3}$ Politeknik Negeri Kupang \\ *E-mail: tsjdonny@gmail.com
}

\begin{abstract}
Abstrak
Agenda prioritas nasional pengembangan Wilayah Strategis Nasional - Kawasan Ekonomi Khusus (WSN KEK) yang berdaya saing perlu dibuat kajian prospektif potensi pengembangan wilayah. Tujuan penelitian untuk pendataan atau identifikasi faktor-faktor strategis prospektif daerah yaitu aspek sosial-budaya-kependudukan, aspek ekonomi, aspek ketahanan pangan, maupun aspek pariwisata yang mendukung pembentukan WSN_KEK Rote Ndao. Metode penelitian menggunakan analisis deskriptif kualitatif-eksploratif, dengan mengunduh data dari website, artikel/jurnal terkait, interview, observasi, dan dokementasi. Hasil penelitian menunjukkan indikator kelayakan pengembangan WSN-KEK Rote Ndao sangat baik dari aspek sosial-budaya-kependudukan, ekonomi, ketahanan pangan, maupun industri pariwisata. Sesuai UU No.39/2009 dan Perpres No.48/2014, maka Kabupaten Rote Ndao dengan kearifan lokal "Lakamola Anan Sio", siap dijadikan salah satu kawasan unggulan ekonomi nasional yang secara demografis dan geografis memiliki nilai ekonomi dan strategis yang tinggi sebagai bagian penting pembangunan nasional yang memiliki comparative advantage dan competitive advantage serta memiliki high economic value dan investment value yang mampu bersaing dengan wilayah startegis lainnya.
\end{abstract}

Kata Kunci : WSN-KEK, Rote-Ndao, comparative-competitive advantage, investment-high economic value

\section{PENDAHULUAN}

Peran dan komitmen negara dalam
rangka meningkatkan kesejahteraan masyarakat seperti yang termandat dalam Undang-Undang Dasar 1945 (UUD 1945) haruslah direalisasikan dengan baik melalui perencaan yang baik pula, dan salah satunya adalah rancangan mengenai kebijakan pengembangan wilayah Kebijakan pengembangan wilayah ini harus dapat menjamin terlaksananya program pemerintah secara nyata dan terukur yang tercantum dalam Rencana Pemerintah Jangka Menengah Nasional (RPJMN) 2015-2019. Hal tersebut menunjukkan bahwa agenda pembangunan Indonesia juga mempertimbangkan agenda prioritas nasional yang menyatakan pentingnya kebijakan, program dan kegiatan yang nyata dan terukur untuk mendorong percepatan pembangunan daerah yang antara lain adalah peningkatan produktivitas rakyat dan daya saing di pasar internasional serta perwujudan kemandirian ekonomi dengan menggerakan sector-sektor strategis ekonomi domestik (Bappenas, 2016).
Kebijakan pengembangan wilayah ini menjadi salah satu instrumen penting dalam mengatasi masalah dan mengoptimalkan potensi daerah, mengurangi kesenjangan antar daerah, mendorong percepatan pembangunan daerah dan mengembangkan daya saing dan keunggulan daerah. Upaya yang dilakukan dalam rangka pengembangan wilayah ini antara lain optimalisasi sumber daya yang dimiliki daerah baik sumber daya alam, sumber daya manusia maupun teknologi dengan tetap mengutamakan pembangunan yang berkelanjutan. Transformasi peningkatan kapasitas sumber daya manusia menjadi peran yang sangat penting dalam peningkatan produktivitas, efisiensi dan nilai tambah sumber daya alam, penguatan kapasitas ilmu pengetahuan dan teknologi, serta penyediaan infrastruktur yang terpadu. Oleh karena itu perlu adanya sinergi yang kuat antara Kementerian/ Lembaga Pemerintah dengan Pemerintah Daerah (Pemerintah Provinsi maupun Kabupaten/ Kota-Pemprov, Pemkab/ Pemkot) dan juga kerjasama/kemitraan dengan pihak swasta. Hal ini untuk memperkuat daya saing daerah guna 
meningkatkan daya saing nasional/internasional (Bappenas, 2016; Junias, 2015).

Terbentuknya pasar Masyarakat Ekonomi ASEAN (MEA) mempengaruhi banyak hal di Indonesia, termasuk perekonomian dan investasi. Pasar MEA ini akan membuka peluang bagi negara anggota ASEAN untuk mampu menarik investasi negara asing, Namun demikian untuk mengantisipasi perubahan regional tersebut maka pemerintah juga dirasa perlu untuk melakukan perbaikan daya saing perekonomian nasional melalui kegiatan investasi yang akan mendorong peningkatan pembangunan dan daya saing daerah maupun nasional dan juga reorientasi kebijakan, program dan kegiatan pembangunan untuk meningkatkan produktivitas dan nilai tambah yang tinggi. Kebijakan dan program pembangunan salah satunya melalui meningkatkan penyiapan wilayah di kawasan strategis, khususnya Kawasan Ekonomi Khusus (KEK).

Dengan adanya pengembangan KEK melalui kegiatan perindustrian, maka diperlukan teknologi dan inovasi yang produktif untuk mendukung hilirisasi pertanian, kelautan dan perikanan serta pertambangan, berbeda dengan kawasan pariwisata yang mengoptimalkan pariwisata daerah dengan pengembangan destinasi wisata, hotel, restoran dan fasilitas lainnya (Bappenas, 2016). Oleh karena itu pengembangan kawasan strategis tidak terlepas dari ketersediaan infrastruktur, sarana- prasarana pendukungnya meliputi jalan, jembatan, pelabuhan, bandara, ketersediaan listrik, air bersih dan sarana/jaringan telekomunikasi yang menjadi instrumen penting dalam pengembangan KEK. Pengembangan kawasan KEK juga perlu didukung pembangunan fisik maupun sumber daya manusia terlebih pengembangan investasi produktif yang fokus pada wilayah, sektor dan komoditas unggulan yang dimiliki (Bappenas, 2016; Junias, 2015).

Analisis yang dilakukan oleh Asia Competitiveness Institute (ACl) mengenai daya saing seluruh provinsi di Indonesia tahun 2013 menunjukkan 4 (empat) ruang lingkup penilaian yakni (1) stabilitas ekonomi makro,(2) perencanaan pemerintahan dan institusi, (3) kondisi keuangan, bisnis, dan tenaga kerja, serta (4) kualitas hidup dan pembangunan infrastruktur. Berdasarkan data hasil survey menunjukkan provinsi Nusa Tenggara Timur (NTT) menempati urutan ke33 dengan skor -0,6014. Hal ini sangat dimungkinkan karena tingkat kesiapan daerah belum memadai dalam mengahadapi persaingan pasar nasional ataupun global apalagi internasional. Kondisi ini bisa disebabkan karena belum adanya regulasi pemerintah daerah yang cukup baik, peran serta/sinergitas masyarakat yang masih rendah, ataupun sarana infrastruktur yang belum memadai (Junias, 2015).

Kawasan NTT yang secara geografis berdekatan dengan beberapa negara tetangga seperti Republik Demokratik Timor Leste dan Australia sangat memungkinkan untuk dapat digunakan sebagai faktor strategis nasional untuk meningkatkan daya saing daerah dan peningkatan kesejahertaan masyarakat lokal (Elim dkk, 2016) Berdasarkan letak geografis Provinsi NTT khususnya Kabupaten Rote Ndao yang berdekatan langsung dengan Negara Australia serta Negara Republik Demokratik Timor Leste dirasa sangat memungkinkan untuk dikembangkan sebagai salah satu kawasan strategis nasional dalam rangka percepatan pembangunan daerah program MP3El koridor $\mathrm{V}$ yang berorientasi pada bidang pariwisata, pertanian dan peternakan yang dapat menjadi "Pintu Gerbang Pariwisata Nasional/ Internasional". Namun demikian pemerintah daerah provinsi belum menggarapnya dengan serius dan hanya fokus pada daerah tertentu saja semisal Kabupaten Alor, Lembata dan Flores Timur, yang pada kenyataannya banyak daerah di NTT yang memliki potensi yang sama ataupun lebih baik dibandingkan dengan daerah dimaksud. Hal ini tentunya berdampak positif pada peningkatan produktivitas masyarakat dan daya saing/keunggulan daerah, kemandirian ekonomi, optimalisasi sumber daya daerah yang dimiliki baik sumber daya alam maupun manusia. Program Prioritas Nasional yaitu percepatan pertumbuhan industri dan kawasan industri yang terimplementasi dalam rencana pembangunan industri bidang ekonomi dan sebaran lokasi Kawasan Ekonomi Khusus (KEK) Indonesia tahun 2014 - 2019, menyebutan bahwa Propinsi Nusa Tenggara Timur termasuk salah satu wilayah yang akan dijadikan KSN dan KEK untuk kawasan Indonesia Timur (Deputi Bidang Ekonomi, BAPPENAS, 2016).

Pembangunan wilayah bertujuan untuk meningkatkan daya saing wilayah, meningkatkan pertumbuhan ekonomi, mengurangi ketimpangan antarwilayah, serta memajukan kehidupan masyarakat. Pembangunan wilayah yang strategis dan berkualitas menjadi harapan setiap daerah di Indonesia (Pemprov NTT, 2015). Pembangunan masyarakat yang berkelanjutan merupakan tujuan pembangunan pemerintah 
yang sangat penting dalam rangka peningkatan kualitas hidup masyarakat, pengembangan daerah dan pemanfaatan sumber daya alam yang optimal, efektif, dan efisien sehingga setiap daerah di Indonesia mampu berubah ke arah yang lebih baik dan dapat memiliki daya saing (competitiveness value) yang tinggi. Dengan demikian kesejahteraan masyarakat yang adil, kemakmuran nasionaldan produktifitasnya akan dapat tercapai dengan baik.

Pengembangan kawasan strategis ini merupakan salah satu upaya dalam rangka percepatan ekonomi yang diharapkan akan membawa dampak positif terhadap pembangunan nasional yang mengarah pada terwujudnya Indonesia yang berdaulat dan mandiri (Bappenas, 2016). Hal ini sejalan dengan misi pembangunan nasional dalam program NAWACITA yang diantaranya yaitu menopang kemandirian ekonomi dengan mengamankan sumber daya maritim, mewujudkan masyarakat maju, berkeseimbangan, dan demokratis, mewujudkan kualitas hidup manusia Indonesia yang tinggi, maju, dan sejahtera, mewujudkan bangsa yang berdaya saing tinggi, mewujudkan Indonesia menjadi negara maritim yang mandiri, maju, kuat, dan berbasis kepentingan nasional.

\section{Kawasan Ekonomi Khusus - KEK}

Dalam Undang-Undang Nomor 39 Tahun 2009 menyebutkan bahwa Kawasan Ekonomi Khusus, yang selanjutnya disebut KEK, adalah kawasan dengan batas tertentu dalam wilayah hukum Negara Kesatuan Republik Indonesia yang ditetapkan untuk menyelenggarakan fungsi perekonomian dan memperoleh fasilitas tertentu. Fungsi dibentuknya KEK ini sesuai pasal 2 UU 39/2009 adalah bahwa KEK dikembangkan melalui penyiapan kawasan yang memiliki keunggulan geoekonomi dan geostrategi dan berfungsi untuk menampung kegiatan industri, ekspor, impor, dan kegiatan ekonomi lain yang memiliki nilai ekonomi tinggi dan daya saing internasional. Sedangkan maksud adanya KEK dalam Peraturan Presiden Nomor 48 Tahun 2014 tentang perubahan atas Peraturan Presiden Nomor 32 Tahun 2011 tentang Masterplan Percepatan dan Perluasan Pembangunan Ekonomi Indonesia 2011 2025, adalah untuk memberi peluang peningkatan investasi melalui kawasan yang memiliki keunggulan (competitiveness) dan nilai ekonomis tinggi (high economic value) seperti perdagangan, pertanian dan kepariwisataan.
Potensi Pengembangan Kawasan Ekonomi Khusus

Tiga dimensi pembangunan terdiri dari tiga hal yaitu dimensi pembangunan manusia, dimensi pembangunan sektor unggulan, serta dimensi pemerataan dan kewilayahan. Pembangunan manusia melalui pembangunan mental dan karakter menjadi salah satu prioritas utama pembangunan, tidak hanya di birokrasi tetapi juga pada seluruh komponen masyarakat, sehingga akan dihasilkan pengusaha yang kreatif, inovatif, punya etos bisnis dan mau mengambil resiko, pekerja yang berdedikasi dan disiplin, kerja keras, taat aturan dan paham terhadap karakter usaha tempat bekerja, serta masyarakat yang tertib dan terbuka sebagai modal sosial yang positif bagi pembangunan, serta memberikan rasa aman dan nyaman bagi sesama. Pembangunan sektor unggulan memiliki prioritas kedaulatan pangan, kedaulatan energi dan ketenagalistrikan, kemaritiman dan kelautan, serta pariwisata dan industri. Selain itu juga, pembangunan dapat menghilangkan/ memperkecil adanya kesenjangan, baik kesenjangan antarkelompok pendapatan, maupun kesenjangan antar wilayah, dengan prioritas wilayah desa, wilayah pinggiran, luar Jawa, dan kawasan timur (Bappenas, 2016).

Terbentuknya pasar tunggal Masyarakat Ekonomi ASEAN (MEA) akan mempengaruhi banyak hal di Indonesia, termasuk perekonomian dan investasi. Adanya pasar MEA ini membuka peluang bagi negara anggota ASEAN untuk menarik investasi asing. Oleh karena itu pemerintah Indonesia perlu melakukan perbaikan daya saing ekonomi nasional dengan cara meningkatkan iklim investasi di daerah yang menjadi salah satu pendorong utama dalam meningkatkan pembangunan dan daya saing daerah maupun nasional.

Adanya reorientasi kebijakan, program dan kegiatan pembangunan diharapkan dapat meningkatkan produktivitas dan nilai tambah yang tinggi. Kebijakan dan program pembangunan salah satunya melalui meningkatkan penyiapan wilayah di kawasan strategis, khususnya Kawasan Ekonomi Khusus (KEK). Dengan adanya pengembangan KEK melalui kegiatan perindustrian, maka diperlukan teknologi dan inovasi yang produktif untuk mendukung hilirisasi pertanian, kelautan dan perikanan serta pertambangan. Berbeda dengan kawasan pariwisata yang mengoptimalkan pariwisata daerah dengan pengembangan destinasi wisata, hotel, restoran dan fasilitas lainnya.

Pengembangan kawasan yang 
didukung dengan pembangunan baik fisik maupun SDM, diperlukan pengembangan investasi. Pengembangan investasi yang produktif dengan fokus wilayah, sektor dan komoditas unggulan yang jelas. Percepatan pembangunan memerlukan peningkatan dalam membangun keunggulan untuk menciptakan daya saing daerah. Keunggulan daerah terbagi menjadi dua, yaitu keunggulan komparatif dan kompetitif guna meningkatkan daya saing.

Keunggulan komparatif daerah dipengaruhi oleh (i) kondisi geografis dan sumber daya alam yang dikelola dengan baik; (ii) penduduk, angkatan kerja dan tenaga kerja terdidik; (iii) infrastruktur yang modern dan merata; dan (iv) kondisi ketertiban dan keamanan daerah yang stabil. Sejalan dengan keunggulan komparatif, terdapat keunggulan kompetitif daerah yang perlu dipertimbangkan dan ditentukan oleh (i) produksi dan jasa berstandar internasional; (ii) produksi dan jasa berstandar internasional; (ii) ikliminvestasi dan iklim usaha yang mendukung; (iii) birokrasi yang lebih baik; (iv) kebijakan pemerintah daerah yang terukur dan jelas; (v) jejaring dan promosi internasional; dan (vi) kerjasama antara pemerintah, swasta dan perguruan tinggi. Dengan adanya keunggulan tersebut diharapkan dapat meningkatkan daya saingdaerah. Peningkatan daya saing daerah diharapkan dapat mengembangkan pusat pertumbuhan, salah satunya melalui pengembangan Kawasan Ekonomi Khusus, baik untuk perindustrian maupun pariwisata (Bappenas, 2016).

Pengembangan wilayah KEK ini juga sejalan dengan Peraturan Presiden Nomor 48 Tahun 2014 tentang perubahan atas Peraturan Presiden Nomor 32 Tahun 2011 tentang Masterplan Percepatan dan Perluasan Pembangunan Ekonomi Indonesia 2011-2025, adalah untuk memberi peluang peningkatan investasi melalui kawasan yang memiliki keunggulan (competitiveness) dan nilai ekonomis tinggi (high economic value) seperti perdagangan, pertanian dan kepariwisataan, dan Provinsi NTT masuk dalam koridor $V$ wilayah Bali - Nusa Tenggara yang fokus pada kegiatan yang bertema "Pintu Gerbang Pariwisata dan Pendukung Pangan Nasional"

Rencana pembangunan Kawasan Ekonomi Khusus (KEK) harus betul-betul disesuaikan dengan potensi daerah serta kesiapan infrastruktur pendukung strategis meliputi seperti air bersih, jalan dan jembatan, listrik, pelabuhan, bandara,dan telekomunikasi, tidak hanya kesiapan dokumen perencanaan implementasi. Pembangunan KEK juga harus disesuaikan dengan kemampuan anggaran daerah yang dimiliki. Dengan demikian perlu adanya sinergi/kerjasama dengan pihak swasta dalam mengelola kesiapan sarana-prasarana infrastruktur (Junias, 2015; Bappenas, 2016; Neno, 2016

\section{METODE PENELITIAN}

Penelitian ini dilakukan di wilayah Kabupaten Rote Ndao, dengan obyek penelitian berkaitan dengan potensi pengembangan kawasan strategis ekonomi khusus yang mana dalam penelitian ini menggunakan pendekatan ekploratif berkenaan dengan kajian-kajian teoritiris maupun empiris dan kebijakan-kebijakan maupun peraturan-peraturan pemerintah yang berlaku sehingga diharapkan mampu memberikan strategi dan kebijakan prioritas pemerintah daerah setempat guna mendukung program pengembangan wilayah KEK dimaksud.

Data penelitian menggunakan data primer yang diperoleh dari hasil observasi atau wawancara dengan pihak yang berkepentingan maupun data sekunder yang diperoleh dari berbagai sumber seperti laporan dari Badan Pusat Statistik (BPS), dataelectronic government (e-gov) pemerintah daerah, maupun dari artikel/kajian teoritismaupun empiris terkait tujuan penelitian.

Teknik pengumpulan data adalah dengan cara mengunduh dari situs atau website terkait seperti BPS Pusat, BPS Daerah NTT serta artikel/jurnal terkait dan juga dengan teknik survei, interview, observasi, dan metode dokementasi, namun dalam aplikasinya bila dianggap perlu, sangat dimungkin untuk mengkombinasi atau memodifikasi teknik-teknik tersebut di atas untuk memperoleh data yang relevan.

Teknik analisa data menggunakan metode analisisdeskriptif kualitatif dengan pendekatan eksplorasi denganmelakukan kajian literatur, artikel maupun jurnal ilmiah, serta melakukan identifikasi, pengumpulan dan analisa informasi dan data terkait pengembangan WSN-KEK (Kab. RoNda). Metode ini dimaksudkan untuk memperoleh informasi kajian faktor/instrumen strategis serta informasi awal yang akan mendukung program pengembangan WSN-KEK Kabupaten RoNda yang akan digunakan sebagai dasar keputusan mengenai strategi, kebijakan dan regulasi Pemkab. RoNda dalam mengimplementasikan program dan kegiatan kerja terkait pengembangan WSN-KEK Kab. RoNda. 
Analisis dilakukan terhadap penilaian aspek sosial kependudukan, ekonomi, ketahanan pangan (kondisi perdagangan, pertanian)serta aspek potensi pariwisata sebagai instrumen awal penilaian kelayakan pembangunan kawasan strategis nasional yang dapat mendukung realisasi rencana pembangunan kawasan ekonomi khusus-KEK dimaksud (Bappenas, 2016).

\section{HASIL DAN PEMBAHASAN}

Rote Ndao merupakan salah satu kabupaten yang berada di Propinsi Nusa Tenggara Timur yang terletak pada $10^{\circ} 25^{\prime}-$ $11^{\circ} 15^{\prime}$ Lintang Selatan dan $121^{\circ} 49^{\prime}-123^{\circ} 26^{\prime}$ Bujur Timur. Kabupaten Rote Ndao terletak di Selatan Indonesia dan berbatasan langsung dengan negara atau benua Australia sehingga memiliki faktor geografis yang sangat strategis untuk pengembangan wilayahnya.

Dengan ibu kota Ba'a, Kabupaten Rote Ndao memiliki luas wilayah $1.280,1 \mathrm{~km}^{2}$ dan berpenduduk sebanyak 153.792 jiwa dengan kepadatan penduduk sebanyak $120 \mathrm{jiwa} / \mathrm{km}^{2}$, dengan kepadatan tertinggi pada Kecamatan Lobalain dengan jumlah penduduk 31.818 jiwa (BPS, 2016).

Seiring dengan dinamisasi perkembangan wilayah yang ada maka saat ini Kabupaten Rote Ndao memiliki 10 (sepuluh) kecamatan yaitu Kecamatan Lobalain, Rote Timur, Pantai Baru, Rote Tengah, Rote Selatan, Rote Barat, Rote Barat Daya, Rote Barat Laut, Landu Leko dan Kecamatan Ndao Nuse, dengan jumlah Desa sebanyak 82 Desa (BPS, 2016).

\section{Gambar 1. Peta Kabupaten Rote Ndao Provinsi} Nusa Tenggara Timur

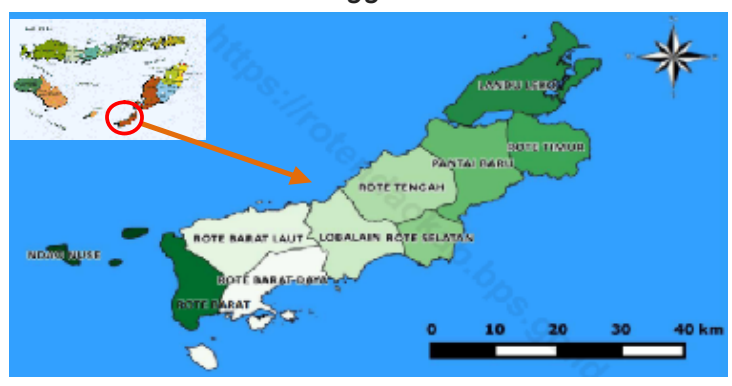

Sumber: www.google.com

Analisis Faktor-Faktor Strategis

Untuk mendukung pembentukan Wilayah Strategis Nasional-Kawasan Ekonomi Khusus (WSN-KEK) di Kabupaten Rote Ndao perlu analisis awal yang tepat mengenai potensipotensi sumber daya yang dimiliki baik sumber daya manusia maupun alam. Hal ini pada akhirnya akan mengarah pada pemberdayaan ekonomi masyarakat dalam kaitan dengan kesejahteraan masyarakat lokal serta mendukung program pemerintah yang berupaya untuk mempercepat perekonomian di wilayah Timur Indonesia. Analisa awal mengenai penilaian aspek sosialkependudukan, ekonomi, serta kondisi perdagangan \& pertanian ataupun pariwisata digunakan sebagai instrumen awal penilaian kelayakan pembangunan WSN yang mendukung realisasi rencana pembangunan KEK dimaksud (Bappenas, 2016).

Undang-Undang Nomor 39 Tahun 2009 menyebutkan bahwa Kawasan Ekonomi Khusus, yang selanjutnya disebut KEK, adalah kawasan dengan batas tertentu dalam wilayah hukum Negara Kesatuan Republik Indonesia yang ditetapkan untuk menyelenggarakan fungsi perekonomian dan memperoleh fasilitas tertentu. Fungsi dibentuknya KEK ini sesuai pasal 2 UU 39/2009 adalah bahwa KEK dikembangkan melalui penyiapan kawasan yang memiliki keunggulan geoekonomi dan geostrategi dan berfungsi untuk menampung kegiatan industri, ekspor, impor, dan kegiatan ekonomi lain yang memiliki nilai ekonomi tinggi dan daya saing internasional. Sedangkan maksud adanya KEK dalam Peraturan Presiden Nomor 48 Tahun 2014 tentang perubahan atas Peraturan Presiden Nomor 32 Tahun 2011 tentang Masterplan Percepatan dan Perluasan Pembangunan Ekonomi Indonesia 2011 -2025, adalah untuk memberi peluang peningkatan investasi melalui kawasan yang memiliki keunggulan (competitiveness) dan nilai ekonomis tinggi (high economic value) seperti perdagangan, pertanian dan kepariwisataan.

Aspek Sosial, Budaya dan Kependudukan Kabupaten ini telah mampu menurunkan angka kemiskinan, dimana pada tahun 2009 sebesar $34,09 \%$ menjadi sebesar $29,60 \%$ pada tahun 2016. Pemerintah daerah setempat, secara terus-menerus memberikan perhatian khusus dan serius dalam upaya mendorong laju percepatan penanggulangan kemiskinan melalui berbagai kebijakan pemerintah yang mendorong kesejahteraan masyarakat setempat.

Pemerintah Kabupaten Rote Ndao juga telah mengimplementasikan sejumlah program dan kegiatan yang dirasa telah mampu meningkatkan kapasitas atau kemampuan sumber daya manusia (SDM) atau masyarakat yang ada. Sasaran utama dari pembangunan di bidang sosial budaya ini adalah dengan meningkatkan mutu aspek SDM, kesejahteraan sosial masyarakat dan berkembangnya nilai-nilai kebudayaan Kabupaten Rote Ndao. Pada aspek 
peningkatan mutu SDM dapat di lihat dari indeks pembangunan manusia yang merupakan komposit dari aspek kesejahteraan ekonomi, pendidikan dan kesehatan dimana pada tahun 2015 sebesar 58,32 dan angka melek huruf tahun 2015 sebesar 91,76\%. Tingkat partisipasi angkatan kerja produktif di Kabupaten Rote Ndao mencapai $70,81 \%$ atau setara dengan 67.782 jwa usia produtif yang bekerja, yang artinya sangat memadai untuk pengembangan kawasan ekonomi yang baik.

Pada aspek kesehatan, Pemerintah Kabupaten Rote Ndao mampu memperluas akses pelayanan kesehatan yang ditandai dengan meningkatnya derajad kesehatan masyarakat dan angka harapan hidup penduduk kabupaten Rote Ndao pada tahun 2009 sebesar 61,79 tahun meningkat menjadi 62,86 tahun pada tahun 2015. Hal tersebut ditunjang dengan keberadaan fasilitas kesehatan masyarakat yaitu 1 Rumah Sakit Umum Daerah, 12 Pusat kesehatan masyarakat (puskesmas), 85 Puskesmas pembantu, 374 Posyandu, 7 Polindes, \& 6 pos kesehatan desa (tersebar di seluruh Kecamatan) dengan 13 orang Dokter, 125 perawat, 78 bidan, \& 25 tenaga farmasi.

Dari sisi pemukiman masyarakat, status kepemilikan tempat tinggal didominasi kepemilikan pribadi (milik sendiri) sebanyak $96,75 \%$ yang mana menunjukkan bahwa sebagian besar masyarakat di Kabupaten ini dapat dikatakan mandiri. Program pembangunan infrastruktur perumahan juga telah berjalan baik mana pada tahun 2009 telah dibangun sebanyak 120 unit meningkat menjadi 1.742 unit pada tahun 2017.

\section{Aspek Ekonomi}

Memasuki fase otonomi daerah sejak pemekaran wilayah tahun 2005, pelaksanaan pembangunan Pemerintah Kabupaten Rote Ndao tetap berpedoman pada Rencana Pembangunan Jangka Menengah Daerah (RPJMD) Tahun 2005-2025, dan labih fokus pada kebijakan pembangunan yang di prioritaskan pada bidang infrastruktur dalam upaya peningkatan produktifitas daerah dengan menghubungkan simpul simpul produksi menjadi suatu kesatuan, sehingga dapat memudahkan akses distribusi/pergerakan barang dan jasa serta mendorong munculnya aktivitas ekonomi baru di lingkungan masyarakat secara berkesinambungan dan berkelanjutan, sedangkan ketersediaan infrastruktur dasar berupa air bersih, perumahan layak huni, energi akan terus ditingkatkan baik secara kuantitas maupun kualitasnya, termasuk di bidang kesehatan, pendidikan, sanitasi dan ekonomi.

Seperti contohnya di bidang ekonomi, dimana pertumbuhan ekonomi Kabupaten Rote Ndao mencapai angka 5,0 \% pada akhir tahun 2016 yang hampir sama dibandingkan dengan pertumbuhan ekonomi secara nasional (BPS, 2016). Disamping itu pertumbuhan PDRB per kapita sebesar Rp.13.302.039 pada tahun 2014 meningkat sebesar 14\% menjadi Rp.15.467.284 di tahun 2016, Pendapatan daerah pada tahun 2009 sebesar Rp.288.615.523.207,- meningkat sebesar $\quad 59,93 \% \quad$ menjadi Rp.720.275.502.554,- pada tahun 2017.

Di bidang infrastruktur, awal tahun 2009 jalan provinsi (hot mix) terbangun sepanjang 7 $\mathrm{km}$ meningkat menjadi $82,64 \mathrm{~km}$ pada tahun 2016, kemudian sepanjang 56,70 km meningkat status menjadi jalan strategis nasional dan sisa jalan provinsi menjadi 25,94 km dan panjang jembatan provinsi yang terbangun sampai dengan tahun 2016 sepanjang 70 meter, jalan kabupaten tahun 2009 sepanjang 68,75 km meningkat menjadi 441,73 km pada tahun 2016 . Panjang jembatan yang terbangun pada tahun 2009 sepanjang 32 meter meningkat menjadi 320 meter pada tahun 2016, panjang dan kualitas prasarana dan fasilitas perhubungan dalam 5 tahun terakhir terus ditingkatkan antara lain landasan pacu Bandara D. C. Saudale, pelabuhan Ba'a, Batutua, Pantai Baru, Papela dan pelabuhan Ndao.

Pada sektor sumber daya energi listrik, tahun 2009 rasio elektrifikasi sebesar 27,80\% meningkat pada tahun 2016 sebesar 74,98\% rumah tangga telah terlayani listrik, dimana pemerintah daerah begitu fokus untuk menyediakan kebutuhan ini melalui berbagai terobosan yakni PLTS tersebar, PLTS terpusat, PLTMH, sehen, KWH meter, PLTD dan saat ini sementara dibangun PLTMGAS dengan kapasitas $6 \mathrm{MW}$ sehingga diharapkan tahun 2019 seluruh Kabupaten Rote Ndao telah berlistrik.

Dari sisi infrastrutur sumber air bersih produksi air bersih mencapai 65 liter/detik dengan kapasitas terjual air minum/air bersih sebanyak 435 ribu m3. Disamping itu pemerintah daerah telah membangun sejumlah embung sebagai sumber ketersediaan air bersih, pada tahun 2009 sebanyak 14 buah meningkat menjadi 185 buah pada tahun 2015 sedangkan saluran irigasi yang dibangun pada tahun 2009 sepanjang 4.300 meter meningkat menjadi 23.275,66 meter pada tahun 2016. Pembangunan tersebut untuk memperkuat ketersediaan sumber air minum yang mana sebagian besar masih menggunakan sumber air 
yang berasal dari sumur maupun mata air alam yang ada.

Ditinjau dari aspek ekonomi, empat lapangan usaha utama di Kabupaten Rote Ndao sebagian besar pada bidang pertanian, kehutanan, perburuan dan perikanan yang mencapai 47.254 orang, bidang public service sebanyak 8.843 orang, dan industry pengolahan sebanyak 4.312 orang, serta bidang perdagangan sebanyak 2.755 orang (BPS, 2016).

\section{Aspek Ketahanan Pangan (Pertanian,} Peternakan, Perdagangan)

Program kerja Pemerintah Kabupaten Rote Ndao tahun 2009-2015 melalui program "Lakamola Anan Sio" dalam upaya peningkatan ketahanan pangan berupa kegiatan bantuan saprodi pada tahun 2010 sebesar Rp.1.369.100.000,- meningkat sebesar 127,65\% pada tahun 2016 menjadi Rp.3.116.850.000,-. Bantuan pupuk pada tahun 2010 sebesar Rp.2.000.000.000,meningkat sebesar $162,46 \%$ pada tahun 2017 menjadi Rp.5.249.307.000,-, pengolahan lahan/ pembukaan lahan pada tahun 2010 sebesar Rp.5.090.000.000,- meningkat sebesar $185,36 \%$ pada tahun 2016 menjadi Rp.14.524.600.000,-.

Penyediaan alat dan mesin pertanian dari tahun 2009-2016 antara lain traktor medium sebanyak 7 unit, hand traktor sebanyak 229 unit, dan mesin pompa air sebanyak 680 unit. Produksi pertanian terutama komoditi padi menempatkan Kabupaten Rote Ndao pada posisi swasembada pangan, dimana pada tahun 2015 produksi padi mencapai 61.171 ton meningkat mencapai $89.731,2$ ton pada musim tanam Oktober 2016 - Maret 2017. Jumlah pengadaan ternak dari tahun 2009-2015 untuk sapi sebanyak 760 ekor, domba sebanyak 40 ekor, kambing etawa sebanyak 130 ekor, babi bibit sebanyak 230 ekor, ayam petelur sebanyak 400 ekor. Untuk tahun 2016 pengadaan ternak sapi kepada masyarakat melalui bantuan keuangan sebanyak 390 ekor dan hibah 195 ekor.

Bagian penting lain penunjang kegitan perdagangan adalah terdapat 4 big trader, 10 medium trader, dan 2.438 small trader/UMKM yang bisa dikembangkan dan dapat mendukung aktifitas ekonomi di kawasan ini. Dengan hadirnya pedagang dan UMKM ini tentunya akan meningkatkan pula perekonomian kawasan Rote Ndao ini sendiri. Sarana perdagangan sebanyak 581 unit pasar, mulai dari pasar tradisonal sampai dengan warung/kios kelontong, dan juga didukung dengan hadirnya koperasi sebanyak 173 unit diberbagai daerah di kawasan ini.

Jumlah ekspor ternak pada tahun 2009 sebanyak 1.783 ekor, meningkat pada tahun 2016 sebanyak 4.882 ekor terdiri dari sapi 3.105 ekor, kerbau 600 ekor, kuda 200 ekor dan kambing 997 ekor. Produksi rumput laut pada tahun 2010 sebanyak 946 ton kering meningkat menjadi 16.074 ton kering pada tahun 2016. Produksi perikanan laut tahun 2010 sebesar 1,517 ton meningkat menjadi 3.310 ton pada tahun 2016 .

\section{Aspek Pariwisata}

Kawasan pariwisata yang baik hendaknya dapat mengoptimalkan kegiatan pariwisata daerah yang sudah ada melalui pengembangan destinasi wisata, hotel, restoran dan fasilitas lainnya. Data BPS 2016 menunjukkan bahwa kegiatan kepariwisataan di Kabupaten Rote Ndao telah didukung dengan ketersediaan infrastrutur hunian hotel yang mencapai 23 Hotel yang terdiri dari beberapa kelas/tingkatan hotel dengan total jumlah kamar mencapai 238 kamar. Hal ini diikuti dengan tersedianya sarana pendukung berupa rumah makan yang merupakan utilitas kegiatan masyarakat sebagai penunjang kegiatan pariwisata di sekitar destinasi wisata yakni sebanyak 37 rumah makan.

Daya tarik wisata di kabupaten ini menunjukkan peningkatan yang signifikan dimana data kunjungan wisata mencapai 3.290 orang wisatawan dengan jumlah wisatawan luar negeri (Foreign) mencapai 1.891 orang $(57,5 \%)$.

Sebagian besar potensi pariwisata merupakan obyek laut atau pantai. Menurut data Dinas Pariwisata (2016) terdapat kurang lebih sebanyak 36 destinasi wisata yang didominasi oleh obyek wisata laut/pantai sebesar $50 \%$. Beberapa destinasi yang terkenal seperti Pantai Nemberala yang telah menjadi salah satu spot International Surfing Tournament. Tidak hanya wisata pantai/laut yang berkembang, tetapi wisata alam dan kawasan bersejarah juga menjadi destinasi menarik bagi wisatwan, semisal Gua Jepang dan Gua Sanilai di daerah Lobalain dan Rote Tengah, Batu Termanu di daerah Rote Tengah, serta beberapa destinasi wisata lainnya. Kesemuanya itu menunjukkan bahwa Kabupaten Rote Ndao juga merupakan salah satu "surga wisata" di kawasan Propinsi Nusa Tenggara Timur yang dapat dikembangkan menjadi kawasan wisata kelas dunia. 
Faktor-Faktor Strategis dalam Pengembangan Wilayah Strategis Nasional dan Kawasan Ekonomi Khusus

Dalam pengembangan kawasan yang didukung dengan pembangunan baik fisik maupun SDM, diperlukan pengembangan investasi. Keunggulan daerah terbagi menjadi dua, yaitu keunggulan komparatif dan kompetitif guna meningkatkan daya saing. Keunggulan komparatif daerah dipengaruhi oleh (i) kondisi geografis dan sumber daya alam yang dikelola dengan baik; (ii) penduduk, angkatan kerja dan tenaga kerja terdidik; (iii) infrastruktur yang modern dan merata; dan (iv) kondisi ketertiban dan keamanan daerah yang stabil.

Sejalan dengan keunggulan komparatif, terdapat keunggulan kompetitif daerah yang perlu dipertimbangkan dan ditentukan oleh (i) produksi dan jasa berstandar internasional; (ii) produksi dan jasa berstandar internasional; (ii) iklim investasi dan iklim usaha yang mendukung; (iii) birokrasi yang lebih baik; (iv) kebijakan pemerintah daerah yang terukur dan jelas; (v) jejaring dan promosi internasional; dan (vi) kerjasama antara pemerintah, swasta dan perguruan tinggi.

Dengan adanya keunggulan tersebut diharapkan dapat meningkatkan daya saing daerah. Peningkatan daya saing daerah diharapkan dapat mengembangkan pusat pertumbuhan, salah satunya melalui pengembangan Kawasan Ekonomi Khusus, baik untuk perindustrian maupun pariwisata (Bappenas, 2016).

Pengembangan wilayah KEK ini juga sejalan dengan Peraturan Presiden Nomor 48 Tahun 2014 tentang perubahan atas Peraturan Presiden Nomor 32 Tahun 2011 tentang Masterplan Percepatan dan Perluasan Pembangunan Ekonomi Indonesia 2011 2025, adalah untuk memberi peluang peningkatan investasi melalui kawasan yang memiliki keunggulan (competitiveness) dan nilai ekonomis tinggi (high economic value) seperti perdagangan, pertanian dan kepariwisataan, dan Provinsi NTT masuk dalam koridor $\mathrm{V}$ wilayah Bali - Nusa Tenggara yang fokus pada kegiatan yang bertema "Pintu Gerbang Pariwisata dan Pendukung Pangan Nasional"

Rencana pembangunan Kawasan Ekonomi Khusus (KEK) harus betul-betul disesuaikan dengan potensi daerah serta kesiapan infrastruktur pendukung strategis meliputi seperti air bersih, jalan dan jembatan, listrik, pelabuhan, bandara, dan telekomunikasi, tidak hanya kesiapan dokumen perencanaan implementasi. Pembangunan KEK juga harus disesuaikan dengan kemampuan anggaran daerah yang dimiliki. Dengan demikian perlu adanya sinergi/kerjasama dengan pihak swasta dalam mengelola kesiapan sarana-prasarana infrastruktur (Junias, 2015; Bappenas, 2016; Neno, 2016).

Perkembangan suatu kota dan wilayah, ditentukan atas empat aspek utama, yaitu aspek ekonomi, aspek sosial budaya, aspek fisik dan aspek lingkungan (Widyaningsih, 2001). Penilaian ekonomi menjadi aspek penting pengembangan wilayah karena dengan mengkaji aspek ini maka dapat ditemukenali potensi-potensi daerah dan sector-sektor apa saja yang dapat didorong atau kembangkan di wilayah tersebut (Sikora 2014). Program Prioritas Nasional yaitu percepatan pertumbuhan industry dan kawasan industri (KEK) yang terimplementasi dalam rencana pembangunan industri bidang ekonomi dan sebaran lokasi KEK Indonesia tahun 2014 - 2019 menjelaskan bahwa Propinsi Nusa Tenggara Timur termasuk salah satu wilayah yang akan dijadikan KSN dan KEK untuk kawasan Indonesia Timur (Deputi Bidang Ekonomi, BAPPENAS, 2016). Dengan demikian program nasional ini merupakan momentum besar dan penting bagi Kabupaten Rote Ndao untuk dapat mengembangkan diri menjadi salah satu kawasan ekonomi penting yang memberikan kontribusi penting bagi perekonomian Negara.

Dengan mengacu pada identifikasi awal, analisis situasi dan strategi pengembangan yang ada, maka dapat dibangun sebuah pemahaman awal yang tepat untuk dapat digunakan sebagai dasar penting dalam membentuk dan mengembangkan wilayah Kabupaten Rote Ndao menjadi salah satu kawasan ekonomi khusus ataupun kawasan strategis nasional yang ada di kawasan Indonesia Timur, khususnya di Propinsi Nusa Tenggara Timur. Hal ini mengarah pada pemberdayaan ekonomi masyarakat dalam kaitan dengan kesejahteraan masyarakat lokal serta mendukung program pemerintah yang berupaya untuk mempercepat perekonomian di wilayah Timur Indonesia. Analisa awal mengenai penilaian aspek sosial kependudukan, ekonomi, serta kondisi perdagangan dan pertanian ataupun pariwisata digunakan sebagai instrumen awal penilaian kelayakan pembangunan WSN yang mendukung realisasi rencana pembangunan KEK dimaksud (Bappenas, 2016).

Hasil analisis menunjukkan bahwa kesiapan Kabupaten Rote Ndao dari aspek sosial, budaya dan kependudukan sangat memenuhi persyaratan untuk dapat dikelola 
dan dikembangkan menjadi salah satu kawasan startegis nasional-kawasan ekonomi khusus (KSN-KEK). Hal tersebut ditunjukan dengan tingkat kesejahteraan masyarakat yang semakin baik dan angka kemiskinan yang semakin menurun. Perbaikan aspek sosial, budaya dan kependudukan ini terjadi karena adanya komitmen penuh kebijakan dan program percepatan pembangunan oleh pemerintah daerah setempat melalui peningkatan kapasitas dan kompetensi sumber daya manusia serta produktifitas tenaga kerja. Hal tersebut juga didukung dengan kesiapan sarana prasarana infrastruktur kesehatan sebagai salah satu persyaratan telah cukup memadai dengan keberadaan fasilitas kesehatan di seluruh daerah kecamatan.

Hasil penelitian menunjukkan bahwa jika ditinjau dari aspek sosial budaya dan kependudukan maka Kabupaten Rote Ndao memiliki keunggulan komparatif yang sangat memadai dimana telah memenuhi salah satu indikator yang menjadi salah satu syarat utama KSN-KEK yaitu dimensi pembangunan manusia (Bappenas, 2016). Dimensi pembangunan manusia dimaksud adalah bagaimana pemerintah daerah mampu meningkatkan kapasitas sumber daya manusia yang memadai sehingga mampu bersaing dengan daerah ataupun negara lain. Kondisi ini sejalan dengan Undang Undang Nomor 39 Tahun 2009 yang menyebutkan bahwa kawasan yang unggul adalah kawasan yang memiliki keunggulan geo-startegis yaitu sumber daya manusia yang unggul.

Hasil penelitian lainnya yang berkaitan dengan aspek ekonomi menunjukkan bahwa kawasan Kabupaten Rote Ndao telah siap menjadi salah satu kawasan KSN-KEK yang mana dapat dilihat mengenai kesiapan sarana prasarana infrastruktur yang cukup memadai. Pembangunan akses jalan raya yang telah menghubungkan seluruh daerah kecamatan sangat memungkinkan untuk peningkatan pembangunan daerah. Infrastruktur pelabuhan laut, telekomunikasi, dan bandar udara akan memudahkan kegiatan investasi-ekonomi yang efektif sehingga akan mempercepat akses komunikasi/ hubungan investasi. Ketersediaan listrik dan air bersih yang sudah cukup memadai juga turut memberikan andil besar dalam pengembangan daerah ini dimana pasokan listrik dan air bersih dirasaakan mampu mendukung aktifitas kegiatan industri lokal yang akan dikembangkan. Hal ini memenuhi indikator pembangunan KSN yaitu dimensi pembangunan sektor unggulan dan pemerataan kewilayahan yang mana akan mampu mendukung kegiatan industri baik lokal maupun kegiatan ekspor impor yang memiliki nilai ekonomi dan daya saing yang tinggi. Dengan demikian bahwa secara aspek komparatif maupun aspek kompetitif, pemerintah daerah Rote Ndao dapat dikatakan telah siap bersaing menuju KSN-KEK sesuai Undang Undang Nomor 39 Tahun 2009.

Seperti aspek sosial, budaya, kependudukan dan juga aspek ekonomi sebagai indikator penilaian kesiapan $\mathrm{KSN}$ $\mathrm{KEK}$, aspek industri perdagangan, pertanian dan peternakan di Kabupaten Rote Ndao juga sangat memungkinkan untuk lebih ditingkatkan menjadi industri kawasan yang mempunyai competitiveness dan high economic value sesuai dengan Peraturan Presiden Nomor 48 Tahun 2014. Hal ini juga ditunjang dengan keunggulan geo-strategi kearifan lokal "Lakamola Anan Sio" yang pada akhirnya mampu meningkatkan ketahanan pangan masyarakat dengan baik. Berdasarkan data yang dianalisis menyebutkan bahwa Kabupaten Rote Ndao memiliki komoditas pertanian unggulan seperti beras, jagung dan bawang merah yang menjadi pemasok utama dikawasan Kota Kupang bahkan lingkungan Propinsi Nusa Tenggara Timur maupun nasional. Disamping itu hasil perkebunan seperti kacang hijau dan komoditas lainnya juga menjadi komoditas utama perdagangan yang tentunya juga berdampak pada perekonomian masyarakat lokal. Keberhasilan di sektor peternakan juga sangat baik dimana menjadi salah satu "lumbung sapi" pada tingkat nasional, serta menjadi salah satu penyedia kebutuhan ikan laut dan rumput laut tertinggi di Indonesia. Data-data tersebut tentunya menjadi salah satu indikator penting keberhasilan Kabupaten Rote Ndao dalam upaya meningkatkan perekonomian masyarakat, yang mana menjadi suatu keunggulan kompetitif dan komparatif yang dapat dikembangkan lagi menjadi sebuah investasi produktif (Bappenas, 2016). Dengan demikian maka pemerintah daerah Rote Ndao dapat dikatakan telah siap bersaing menuju KSN-KEK sesuai Undang Undang Nomor 39 Tahun 2009 dan Peraturan Presiden Nomor 48 Tahun 2014.

Dari aspek kepariwisataan, ketersediaan sarana prasarana infrastruktur dan pembangunan fisik destinasi wisata, hotel dan transportasi yang sudah memadai akan dapat memacu peningkatan kegiatan industri yang produktif dan kompetitif di sektor pariwisata. Keseriusan pemerintah sudah dilaksanakan secara baik dimana telah dilakukan perbaikan-perbaikan dan peningkatan fasilitas dan infrastruktur yang 
mendukung seperti jalan raya, ketersediaan listrik sarana pariwisata serta ketersediaan air bersih sebagai kelengkapan fasilitas hunian hotel. Semua kemajuan tersebut juga dapat terjadi karena peran seluruh masyarakat lokal dan pemerintah daerah setempat yang berkomitmen untuk menjadi salah satu destinasi wisata terbaik internasional selain destinasi wisata yang ada di Propinsi Nusa Tenggara Timur lainnya. Dengan keunggulan geografis yang dimiliki sangat terbuka peluang untuk pengembangan industri pariwisata yang dicanangkan pemerintah pusat melalui program masterplan percepatan pembangunan ekonomi Indonesia sampai tahun 2025.

Oleh karena itu secara keseluruhan, berdasarkan hasil analisis awal terhadap indikator-indikator penilaian kelayakan pengembangan kawasan strategis nasionalkawasan ekonomi khusus yang ditetapkan Badan Perencanaan Nasional (Bappenas) maka wilayah Kabupaten Rote Ndao dirasa sudah sangat mumpuni dalam aspek sosial budaya kependudukan, aspek ekonomi, aspek ketahanan pangan, maupun aspek industri pariwisata. Hasil penelitian ini juga menunjukkan bahwa sesuai dengan Undang Undang Nomor 39 Tahun 2009 dan Peraturan Presiden Nomor 48 Tahun 2014, maka Kabupaten Rote Ndao siap dijadikan salah satu kawasan unggulan ekonomi nasional dimana secara demografis dan geografis memiliki keunggulan ekonomis dan strategis sebagai bagian penting pembangunan nasional yang memiliki comparative advantage dan competitive advantage serta memiliki high economic value dan investment value yang mampu bersaing dengan wilayah startegis lainnya.

\section{PENUTUP}

Secara keseluruhan, indikator-indikator penilaian kelayakan pengembangan kawasan strategis nasional-kawasan ekonomi khusus yang ditetapkan maka wilayah Kabupaten Rote Ndao dirasa sudah sangat mumpuni ditinjau dari aspek sosial budaya kependudukan, aspek ekonomi, aspek ketahanan pangan, maupun aspek industri pariwisata. Hasil penelitian ini menunjukkan bahwa sesuai dengan Undang Undang Nomor 39 Tahun 2009 dan Peraturan Presiden Nomor 48 Tahun 2014, maka Kabupaten Rote Ndao dengan kearifan lokalnya "Lakamola Anan Sio", siap dijadikan salah satu kawasan unggulan ekonomi nasional dimana secara demografis dan geografis memiliki keunggulan ekonomi dan strategis sebagai bagian penting pembangunan nasional yang memiliki comparative advantage dan competitive advantage serta memiliki high economic value dan investment value yang mampu bersaing dengan wilayah startegis lainnya. Kesiapan tersebut didukung pula dengan adanya Program Prioritas Nasional yaitu percepatan pertumbuhan industri dan kawasan industri (KEK) yang terimplementasi dalam rencana pembangunan industri bidang ekonomi dan sebaran lokasi KEK Indonesia tahun 20142019, yang menyebutkan bahwa Propinsi Nusa Tenggara Timur termasuk salah satu wilayah yang akan dijadikan KSN dan KEK untuk kawasan Indonesia Timur.

Oleh karena itu diperlukannya komitmen bersama dan sinergitas yang tinggi antar seluruh komponen stakeholder yaitu pemerintah pusat, pemerintah daerah Kabupaten Rote Ndao, masyarakat lokal/ regional, pihak swasta yang terlibat serta dukungan luar negeri untuk dapat terus memacu percepatan pembangunan daerah sehingga keunggulan-keunggulan daerah yang dimiliki dapat dioptimalkan dalam mencapai daya saing nasional dan internasional..

\section{DAFTAR PUSTAKA}

Direktorat Pengembangan Wilayah Kementerian Perencanaan Nasional/Badan Perencanaan Nasional (2016), Kajian Pengembangan Model Investasi Wilayah RKP 2016, Bappenas, Jakarta

Elim, M. A., Lobo Pa A. \& Suharto R.S.B. (2016), Kajian Tentang Pembentukan Kawasan Ekonomi Khusus Kabupaten Kupang, Analisis Peluang dan Tantangan Pertumbuhan Ekonomi Daerah dan Pendapatan Asli Daerah, Kemristekdikti-Politeknik Negeri Kupang, Kupang

Junias, D. T. S. (2014), Analisis Strategi Pengembangan Industri Pariwisata Kota Kupang, Politeknik Negeri Kupang, Kupang

Junias D. T. S. \& Suharto R. S. B. (2014), Analisa Faktor Determinan Industri Pariwisata Terhadap Pendapatan Asli Daerah Nusa Tenggara Timur, Politeknik Negeri Kupang, Kupang

Junias, D. T. S. (2015), Analisis Strategi Pengembangan Industri Pariwisata Sebagai Alternatif Peningkatan Ekonomi Masyarakat, Makalah Procceding Fakultas Ekonomi dan Bisnis 
Universitas Nusa Cendana, Kupang.

Neno J. A. (2016), Bangun Kawasan Ekonomi Khusus Perlu Disesuaikan Potensi Daerah, NTT Online.com, Sumber: http://www.nttonlinenow.com/new2016/2016/08/04/bangun-kawasanekonomi-khusus-perlu-disesuaikandengan-potensi-daerah/ diakses tanggal 25 Mei 2017

Pemerintah Provinsi Nusa Tenggara Timur (2015), Seri Analisis Pembangunan Wilayah Provinsi Nusa Tenggara Timur 2015, Pemerintah Provinsi Nusa Tenggara Timur, Kupang

Undang-Undang Nomor 39 Tahun 2009 Tentang Kawasan Ekonomi Khusus, Sekretariat Negara Republik Indonesia, Jakarta

Peraturan Presiden Nomor 32 Tahun 2011 tentang Masterplan Percepatan dan Perluasan Pembangunan Ekonomi Indonesia 2011 -202, Sekretariat Negara Republik Indonesia, Jakarta

Peraturan Presiden Nomor 48 Tahun 2014 tentang Perubahan atas Peraturan Presiden Nomor 32 Tahun 2011 tentang Masterplan Percepatan dan Perluasan Pembangunan Ekonomi Indonesia 2011 -2025, Sekretariat Negara Republik Indonesia, Jakarta

Undang-Undang Nomor 17 Tahun 2007 tentang Rencana Pembangunan Jangka Panjang Nasional 2005-2025 dan Rencana Pembangunan Jangka Menengah Nasional (RPJMN) 2015 2019, Sekretariat Negara Republik Indonesia, Jakarta 